\title{
HIV/AIDS prevention interventions in African American heterosexuals
}

\author{
Matthew Asare \& Manoj Sharma \\ University of Cincinnati, Health Promotion \& Education
}

\begin{abstract}
Background: The purpose of this paper was to review the HIV/AIDS interventions conducted among heterosexual African Americans, and suggest ways of enhancing these interventions. Methods: In collecting the materials for this study, a search of CINAHL, ERIC, and MEDLINE databases were carried out for the time period of 2002 to July 2010. The inclusion criteria for the studies were (1) African American adults; (2) limited to heterosexual African American populations; (3) publication in refereed journals in the English language; (4) location of the study in the United States. Results: A total of twelve studies met the inclusion criteria, eight of which took place in a clinical setting. Nine of the interventions were based on behavioral theories and six of those interventions utilized social cognitive theory. The themes used were HIV/AIDS knowledge, risk reduction strategies, behavioral skills, condom use, selfefficacy, and communication about sex and goal setting. The review found that all the interventions were effective, though the effect sizes were generally small. Conclusions: The strengths of the interventions include the use of the following: appropriate sample sizes, post intervention follow-ups, and the use of randomized control trial design. Recommendations for enhancing the effectiveness of HIV/AIDS interventions in African American heterosexuals are presented.
\end{abstract}

(C) 2010 Californian Journal of Health Promotion. All rights reserved.

Keywords: HIV/AIDS, programs, safer sex, heterosexual

\section{Introduction}

The first incidence of Human immunodeficiency virus/Acquired immunodeficiency syndrome (HIV/AIDS) was reported in the United States (U.S.) in 1981, since then the HIV/AIDS prevalence rate has increased at an alarming rate in the U.S. In 2010 the Centers for Disease Control and Prevention (CDC) estimated that more than one million people in the U.S. are living with HIV and about $21 \%$ of those living with HIV are unaware of their status. The number of new HIV infections has remained relatively stable in recent years with an average of 56,300 each year (CDC, 2010).

The characteristics of those who are infected with HIV/AIDS in the U.S. changed in a number of ways. Racial and ethnic minority populations, especially African Americans, have been disproportionately affected by this infection (Jemmott, Jemmott, \& Fong, 1992). Prior to 1995, HIV diagnoses among non-Hispanic whites were higher than minority ethnic/racial groups, accounting for about $47 \%$ of AIDS diagnoses. However, over time, the proportion of the HIV cases among racial/ethnic subgroups has increased. Although African Americans represent approximately 13 percent of the U.S. population, they account for a disproportionate number of HIV/AIDS cases. In 2006, there were approximately 1 million people in the U.S. who were living with the HIV virus; of this number, 47\% were African Americans, 34\% Whites, $17 \%$ Hispanics, and other ethnic groups comprised the remaining 2\% (CDC, 2009).

From 2005-2008, the rate of HIV diagnoses among blacks increased from 68 per 100,000 persons to 74 per 100,000 . This increase reflects the largest increase in rates of HIV diagnoses in African Americans (CDC, 2010)

Currently, there is no vaccine that can reliably prevent HIV/AIDS infection; however the best possible alternative to control the transmission of this infection is through attitudinal and 
behavioral modification interventions (Edgar, Fitzpatrick, \& Freimuth, 1992; Maibach, Kreps, \& Bonaguro, 1993; Freimuth, Hammord, Edgar, \& Monahan, 1990; World Health Organization, 1988; Melkote, Muppidi, \& Goswami, 2000). Consequently, several intervention programs have been implemented to reduce the risk of HIV/AIDS on the African-American population. In the last decade, HIV intervention programs have been implemented to target behavioral changes in certain African-American subgroups: heterosexual adults (Neumann et al., 2002); men who have sex with men (Johnson et al., 2002; Rhodes et al., 2010); sexually experienced adolescents (Mullen, Ramirez, Strouse, Hedges, \& Sogolow, 2002); drug users (Semaan et al., 2002; Wagner, Unger, Bluthenthal, Andreeva, Pentz, 2010); and women (Betancourt, Abrams, McBain, Fawzi, 2010; Logan, Cole, \& Leukefeld, 2002).

The purpose of this paper is to review all interventions implemented after 2002 targeting preventive efforts in heterosexual AfricanAmericans living with HIV/AIDS. Our discussion is limited to this subgroup primarily because the incidence and prevalence of HIV cases among African American heterosexuals continues to rise disproportionately. According to the CDC (2009), the largest estimated proportion of HIV/AIDS diagnoses among adults and adolescents were men who have sex with men, who accounted for $53 \%$ of all diagnoses in 2007. The second largest group with an HIV diagnosis was heterosexuals, which accounted for $32 \%$ of the overall cases. African Americans accounted for $59 \%$ of heterosexual persons at high risk for contracting the HIV infection. Of all African American women living with HIV/AIDS in 2005, the primary mode of transmission was high-risk heterosexual contact, followed by injection drug use (CDC, 2007a). We will first briefly discuss the determinants of HIV/AIDS among African Americans and the methodology used to review the articles. In the subsequent sections, we will discuss the interventions as well as the salient implications for instituting them into practice.

\section{Determinants of HIV/AIDS}

Several factors have contributed to the high rate of HIV infection among African Americans. Factors such as racism and discrimination, poverty, denial, stigma, homophobia, and limited access to health care have contributed to the increased susceptibility of African Americans to the HIV infection in comparison to other ethnic groups (CDC, 2007a). First, denial plays a major role in the increased vulnerability of the African American community. Since HIV/AIDS cases were first reported among white gays in the early 1980s, some African Americans still think that HIV/AIDS is not a concern for their community and that HIV/AIDS is primarily a disease of gay white men. Many African Americans also consider it taboo to talk openly about topics such as sexuality, homosexuality, sex outside marriage, drug use, and other sensitive and private issues. Silence on such issues makes raising awareness about HIV/AIDS a challenge (CDC, 2007b). Another aspect of denial is the conspiracy beliefs among African Americans about HIV/AIDS. A significant number of African Americans have endorsed the belief that HIV/AIDS is a manmade virus that the federal government created to control the African American population (Bogart \& Thorburn, 2005; Klonoff \& Landrine, 1999). African Americans mistrust of the government originates from historical and current racial discrimination in the U.S. health care system; a perfect example is the Tuskegee syphilis study (Bogart \& Thorburn, 2005, p. 213). Because of mistrust and the conspiracy belief, most African Americans tend to shy away from public health messages about safer sex, such as condom use. For example, Bogart \& Thorburn (2005) concluded in their study that the HIV/AIDS conspiracy belief is a barrier to HIV prevention among African Americans, and contributes to negative attitudes about condom use among African American men.

The presence of certain Sexually Transmitted Infections (STIs), such as Gonorrhea, Chlamydia and Syphilis increase the chances of contracting the HIV virus, and the chances of 
contracting the infection are increased when a person has both HIV and an STI. Issues such as substance abuse (including injection drug use), mental health problems, childhood sexual abuse, and other psychological stressors may make it difficult for people to protect themselves and their partners (CDC, 2007b). Research suggests that mental health problems and childhood sexual abuse increase the likelihood of engaging in drug abuse and high risk sexual behaviors, such behaviors increase the risk of the HIV infection (Mimiaga et al., 2009; Jones et al., 2010). The incarceration of African American men is another significant determinant for HIV risk. More than one in ten African American men in their twenties and thirties are incarcerated in U.S. prisons and jails, where inmates are at high risk of contracting the HIV infection (National Alliance of State and Territorial AIDS Directors, 2005). Studies have found that there is a high rate of HIV cases among incarcerated men because some inmates tend to share used needles to "shoot up" drugs, while other men have unprotected sex with men (MSM). Some of these men are bisexual who end up having sex with women (CDC, 2007b)

A considerable number of people avoid HIV testing because of the stigma associated with the infection. Potential infected victims fear that when their HIV status is known, it may lead to rejection by their family members, friends, and coworkers. The danger of unknown HIV status is the risk of continued transmission to others and not receiving the proper treatment. According to the CDC (2007b), undiagnosed HIV infection is responsible for over $50 \%$ of the new infections sexually transmitted each year. Denial about HIV might be a reason why a large percentage of African Americans who are HIV infected do not get tested (2007b),

\section{Methods}

In order to collect the data for the study, a search of MEDLINE, ERIC, and CINAHL databases was conducted for published studies between 2002 and July 2010. The year 2002 was chosen because review articles (Johnson et al., 2002; Mullen, Ramirez, Strouse, Hedges, \& Sogolow,
2002; Neumann et al., 2002; Semaan et al., 2002) were published in 2002. After these articles were published, we did not find any other review that specifically focused on African American heterosexuals; hence the purpose of this study was to examine interventions published after the aforementioned articles. Keywords used to identify articles included HIV/AIDS, African American, African American women/men, minority women, heterosexual and intervention.

In MEDLINE, a total of 215 articles were found with various combinations of the above key words. In ERIC, a total of 339 articles were found and in CINAHL 372 articles were found. Abstracts of all these articles were read and the following inclusion criteria were used in making final selection of the articles. Besides the time period of 2002 to 2010, other inclusion criteria were: (1) articles published in refereed journals; (2) studies reported in English; (3) studies conducted in the United States (4) studies that focused on heterosexual men and/or women, (5) studies that had a sample of at least $50 \%$ of African American, and (6) studies with sample of adults at least 18 years of age. Studies that did not meet the above listed inclusion criteria were excluded from this review. Effect sizes for all studies with significant findings were calculated using G*Power, Version 3.1 (Erdfelder, Faul, \& Buchner, 1996).

\section{Results}

A total of twelve studies met the inclusion criteria for this review. Four studies focused exclusively on African Americans and the remaining eight studies had study populations which included anywhere from $51 \%$ to $87 \%$ African American subjects. One study exclusively sampled African American men; four sampled both men and women and the remaining seven sampled women alone. All the studies under review were published in refereed journals. Table 1 presents a summary of the nine studies included in the review that utilized social cognitive theory. Table 2 summaries the interventions that used other theories and models, and table 3 presents a summary of 
atheoretical interventions (See Appendix).

All twelve of the HIV risk reduction intervention studies found that their intervention was successful (meaning, that they found significant results for their intervention). They all revealed that there was a significant reduction of unprotected sex and an improvement in safer sex behaviors among the participants. The main behavioral variables that the interventions targeted were unprotected sexual intercourse, condom use knowledge, beliefs regarding effect of condom use, sexual partners' reaction to condom request, self efficacy to achieve consistent condom use, improved perception about HIV related stigma, and reduction of STDs.

Most of the interventions were designed based on a specific theory or model. In fact, nine out of twelve interventions were based on behavioral theories such as social cognitive theory, AIDS reduction model, and information-motivation behavioral skills (El-Bassel, et al., 2010; Crosby et al., 2009; O'Leary et al., 2008; Sikkema et al., 2008; Abel, 2007; Jemmott et al., 2007; Kalichman et al., 2005; Legardy et al., 2005; Metcalf et al., 2005; Wingood, et al. 2004; Ehrhardt et al., 2002; Hobfoll, Jackson, Lavin, Johnson, \& Schroder, 2002). Six of those studies used the social cognitive theory. Among studies using the social cognitive theory, the self efficacy construct was the primary focus in the interventions.

\section{Discussion}

The purpose of this article was to examine interventions designed to prevent HIV/AIDS among the African-American heterosexual community, and use the review findings to make informed recommendations for future HIV interventions. The effect sizes of these studies have generally been small from 0.02 to 0.27 . The mean effect size of the six studies that utilized social cognitive theory was about 0.08 and that of the other three studies that used different theories or models was 0.06 . The three interventions which did not utilize any theory had a mean effect size of 0.15 . The atheoretical based interventions yielded significant results in addition to a relatively large effect size. The downfall in utilizing atheoretical behavioral interventions is how the conceptual framework is difficult to explain and the intervention as a whole is difficult to replicate. Also, it is difficult to ascertain from these interventions what components work and to what extent. The frequent use of theoretical frameworks, especially the use of social cognitive theory in designing HIV interventions, may have contributed to the success of those interventions. Theory helps in the design of intervention programs and the dissemination of the results in a scientific manner (Sharma \& Romas, 2008). It helps in identifying which constructs of the theory are working and which ones are not. It helps in sequencing the intervention and reduces the duration of the intervention by focusing on important aspects. Further theory improves program efficiency and effectiveness (Sharma \& Romas, 2008). Therefore, more theory- based research and interventions should be conducted among African-American heterosexuals to reduce the spread of HIV disease. Further, it has been found that six interventions (half of those reviewed) used social cognitive theory and all these interventions registered significant effects which favor use of this theory by future interventions. Lopez and colleagues (2009) also found social cognitive theory to be an effective theory for improving contraceptive use, which is a protective behavior against STIs and HIV.

Culturally sensitive interventions were found to yield significant results in the ethnic minority populations (El-Bassel et al., 2010; Hobfoll, Jackson, Lavin, Johnson, \& Schroder, 2002). Two of the studies included cultural components in the intervention and these interventions revealed significant results (El-Bassel et al., 2010; Hobfoll, Jackson, Lavin, Johnson, \& Schroder, 2002).

Beatty, Wheeler \& Gaiter (2004) observed that "Incorporating cultural components into programs for African American participants seems to benefit HIV/AIDS and drug interventions" (p.45). These findings therefore suggest that African Americans respond to interventions that are culturally sensitive to their needs and more of these types of evidence-based 
interventions should be implemented to help reduce the spread of the HIV virus.

In addition, all the interventions except one (Abel, 2007) included in the review used appropriately large sample sizes which increased the strength of the findings. The use of appropriate sample sizes in the intervention groups increase the likelihood of detecting any effect of the intervention implemented. To attain sufficient power, an appropriate sample size should be used and it can also help the researchers to analyze other demographic factors that can affect the results of the interventions. Only four of the articles (Crosby et al., 2009; Jemmott et al., 2007; Legardy et al., 2005; Sikkema et al., 2008) provide information about the economic status of the participants. A failure to closely examine socio-economic status, education level, geographic migration, and other social-political-cultural factors such as community violence, may mask the importance of intragroup differences influencing individuals' behavior (Melkote, Muppidi, \& Goswami, 2000). Thus, there is an acute need for future interventions to target discrete subpopulations of African Americans; studies that have sufficient sample sizes should adequately assess within -group differences that affect their sexual behaviors.

Another strength of the studies reviewed is the use of randomized controlled trial design (RCT). With the exception of one study (Abel, 2007) which did not use RCT, all studies utilized RCT increased the ability to establish causality between the behavioral variables and the interventional maneuvers introduced in the studies. Each study allowed a period of time to elapse between the introduction of the intervention and the outcome measurement. For example, nine of the articles reviewed (Crosby et al., 2009; Ehrhardt et al., 2002; El-Bassel, et al., 2010; Hobfoll, Jackson, Lavin, Johnson, \& Schroder, 2002; Jemmott et al., 2007; Kalichman et al., 2005; Metcalf et al., 2005; O'Leary et al., 2008; Sikkema, et al., 2008; Wingood, et al. 2004) allowed for at least a 6month interval between the completion of the interventions and the measurement of the outcome. This assessment of long-term behavior change should be a determining factor in the adoption of interventions for future practice.

Furthermore, common issues mentioned in the examined studies were treatment integrity problems and attrition rates. However, except for Abel (2007) and Sikkema et al., (2008), high attrition was a major issue. Crosby et al., (2009), and Jemmott et al., (2007) for instance, reported that at least $25.9 \%$ did not return to complete the 3-month follow-up but they were able to determine that there was no significant difference between those who dropped out and those who remained in the program. Reporting treatment integrity problems provide a more accurate interpretation of findings. All future HIV/AIDS interventions should report attrition rates and how it affects the findings.

Eleven of the twelve interventions were introduced in clinic-based settings (Crosby et al., 2009; Ehrhardt et al., 2002; Hobfoll, Jackson, Lavin, Johnson, \& Schroder, 2002; Jemmott et al., 2007; Kalichman et al., 2005; Legardy et al., 2005; Metcalf et al., 2005; O'Leary et al., 2008; Sikkema et al., 2008; Wingood, et al. 2004) and one intervention was community-based (Abel, 2007). Since none of the studies analyzed the impact of the intervention settings on the efficacy of the interventions, one must be careful to draw the conclusion that clinic-based HIV interventions are always good in the African American community. Future studies should analyze how settings within which preventive efforts are introduced play a role in changing African Americans' sexual behavior.

Another area of concern in the interventions analyzed is the administration of the actual programs and/or education provided to the participants. While some of the articles listed the steps of the treatments, most of the studies did not give details as to how the education programs were executed. It is important to give the details of the program so that the study can be replicated to validate the findings. Furthermore giving treatment without monitoring the adherence to the program could be a waste of resources. 
Another limitation that has been found in some of the reviewed interventions is that instruments have been used but the researchers did not provide the results of the instruments' validity and reliability. However, Kalichman et al., (2005) and Wingood, et al. (2004) documented the validity and reliability results of their instruments. The testing for validity and reliability of instruments must be reported so as to increase the confidence in the findings of the studies.

\section{Recommendations for future interventions}

For future intervention research, it is recommended that researchers should continue to use larger samples to attain enough power to do subgroup analyses among participants. In order to ascertain good sample size G Power analysis could be used. According to G Power analysis when a researcher sets apriori an alpha of 0.05 , power of 0.80 , and an effect size of 0.20 , and a repeated measures analysis of variance technique with at least 3 groups, a sample size of 42 should be utilized in the study (Erdfelder, Faul, \& Buchner, 1996). It is vital for effective implementation of future interventions to consider the economic and educational backgrounds of the participants. These demographic attributes can be possible mediators, which not only affect the behavioral variables being measured, but also have an impact on the success of the interventions. Researchers should continue to use RCT and randomly assign participants to experimental and comparison groups in order to accurately assess the intervention as effective or not. Future interventions should be based on a theoretical framework. Social cognitive theory seems to be a useful theory in the context of HIV/AIDS intervention in the African American community. Particularly the construct of selfefficacy has been found to have empirical support and should be incorporated in future interventions. Researchers should try as much as possible to use instruments with documented validity and reliability.

\section{References}

Abel, E. (2007). Women with HIV and stigma. Family Community Health, 30(1), S104 - S114. Retrieved from http://journals.lww.com/familyandcommunityhealth/pages/default.aspx

Beatty, L. A., Wheeler, D., \& Gaiter, J. (2004). HIV prevention research for African Americans: Current and future directions. Journal of Black Psychology, 30(1), 40-58. doi:10.1177/00957984032592 45

Betancourt, T. S., Abrams, E. J., McBain, R., \& Fawzi, M. C. (2010). Family-centered approaches to the prevention of mother to child transmission of HIV. Journal of the International AIDS Society, 13(Suppl 2), S2.

Centers for Disease Control and Prevention. (2007a). HIV/AIDS among African Americans fact sheet. Retrieved from http://www.cdc.gov/hiv/topics/aa/resources/factsheets/aa.htm

Centers for Disease Control and Prevention. (2007b). A heightened national response to the HIV/AIDS crisis among African Americans. Retrieved from http://www.cdc.gov/hiv/topics/aa/resources/reports/ heightendresponse.htm\#t1

Centers for Disease Control and Prevention. (2009). HIV/AIDS among African Americans. Retrieved from http://www.cdc.gov/hiv/topics

Centers for Disease Control and Prevention. (2010). HIV/AIDS in the United States. Retrieved from http://www.cdc.gov/hiv/resources/factsheets/us.htm

Crosby, R., DiClemente, R. J., Charnigo, R., Snow, G., \& Troutman, A. (2009). A brief, clinic-based, safer sex intervention for heterosexual African American men newly diagnosed with an STD: A randomized controlled trail. American Journal of Public Health, 99, S96-S103. doi:10.2105/ AJPH.2007.123893

Edgar, T., Fitzpatrick, M., \& Freimuth, V. (Eds.). (1992). AIDS: A communication perspective (pp. xixiii). Mahwah, NJ : Erlbaum.

Ehrhardt, A. A., Exner, T. M., Hoffman, S., Silberman, I., Leu, C-S., Miller, S., et al. (2002). A genderspecific HIV/STD risk reduction intervention for women in a health care setting: short and long- 
term results of a randomized clinical trial. AIDS Care, 14(2), 147-161. doi:10.1080/095401202 20104677

El-Bassel, N., Jemmott, J. B., Landis, J. R., Pequegnat, W., Wingood, G. M., Wyatt, G. E., et al. (2010). National Institute of Mental Health multisite Eban HIV/STD prevention intervention for African American HIV serodiscordant couples. Archives of Internal Medicine, Retrieved from http://archinte.ama-assn.org/cgi/reprint/2010.261v1

Erdfelder, E., Faul, F., \& Buchner, A. (1996). GPOWER: A general power analysis program. Behavior Research Methods, Instruments, \& Computers, 28, 1-11.

Freimuth, V. S., Hammond, S. L., Edgar, T., \& Monahan, J. L. (1990). Reaching those at risk: A contentanalytic study of AIDS PSAs. Communication Research, 17, 775 - 791

Hobfoll, S. E., Jackson, A. P., Lavin, J. Johnson, R. J., \& Schroder, K. E. E. (2002). Effects and generalizability of communally oriented HIV-AIDS prevention versus general health promotion groups for single, inner-city women in urban clinic. Journal of Consulting and Clinical Psychology, 70(4), 950- 960. Doi:10.1037//0022-006x.70.4.950

Jemmott, J. B. III., Jemmott, L. S., \& Fong, G. T. (1992). Reduction in HIV risk-associated sexual behaviors among black male adolescents effects of an AIDS prevention intervention. American Journal of Public Health, 82, 372 - 377. doi:10.2105/AJPH.82.3.372

Jemmott, L. S., Jemmott, J. B., III., \& O'Leary, A. (2007). Effects of sexual risk behavior and STD rate of brief HIV/STD prevention interventions for African women in primary care settings. American Journal of Public Health, 97, 1034 - 1040. doi:10.2105/AJPH.2003.020271

Johnson, W. D., Hedges, L. V., Ramirez, G., Semaan, S., Norman, L. R., Sogolow, E., et al. (2002). HIV prevention research for men who have sex with men: A systematic review and meta analysis. Journal of Acquired Immune Deficiency Syndromes, 30, S118-S129. doi: 10.1097/01.QAI.0000 018918.84759 .19

Jones, D.J., Runyan, D.K., Lewis, T., Litrownik, A.J., Black, M.M., Wiley, T., English, D.E., Proctor, L.J., Jones, B.L., Nagin, D.S. (2010). Trajectories of childhood sexual abuse and early adolescent HIV/AIDS risk behaviors: the role of other maltreatment, witnessed violence, and child gender. Journal of Clinical Child and adolescent psychology: The Official Journal for Clinical Child and Adolescent Psychology, 39(5), 667-680

Kalichman, S. C., Cain, D., Weinhardt, L., Benotsch, E., Presser, K., Zweben, A., et al. (2005). Experimental components analysis of brief theory-based HIV/AIDS risk-reduction counseling for sexually transmitted infection patients. Health Psychology, 24, 198 - 208. doi:10.1037/02786133.24.2.198

Legardy, J. K., Macaluso, M., Artz, L., \& Brill, I. (2005). Do participant characteristics influence the effectiveness of behavioral interventions? Promoting condom use to women. Sexually Transmitted Diseases, 30, 665 - 671. doi:10.1097/01.olq.0000175392.84989.ec

Logan, T. K., Cole, J., \& Leukefeld, C. (2002).Women, sex, and HIV: Social and contextual factors, meta-analysis of published interventions, and implications for practice and research. Psychological Bulletin, 128, 851-885. doi: 10.1037//0033-2909.128.6.851

Lopez, L. M., Tolley, E. E., Grimes, D. A., \& Chen-Mok, M. (2009). Theory-based strategies for improving contraceptive use: A systematic review. Contraception, 79(6), 411-417.

Maibach, E., Kreps, G. \& Bonaguro, E. (1993). Developing strategic communication campaigns for HIV/AIDS prevention. In S. Ratzan (Ed.), AIDS: Effective health communication for the 90s. Washington, DC: Taylor \& Francis.

Mimiaga, M.J., Noonan, E., Donnell, D., Safren, S.A., Koenen, KC.., Gortmaker, S., O'Cleirigh, C., Chesney, M.A., Coates, T.J., Koblin, B.A., Mayer, K.H. (2009). Childhood sexual abuse is highly associated with HIV risk-taking behavior and infection among MSM in the EXPLORE Study. Journal of Acquired Immune Deficiency Syndromes, 51(3), 340-348.

Melkote, S. R., Muppidi, S. R., \& Goswami, D. (2000). Social and economic factors in an integrated behavioral and societal approach to communication in HIV/AIDS. Journal of Health 
Communication, 5, S17 - S27. Retrieved from http://www.tandf.co.uk/journals/titles/ 10810730.html

Metcalf, C. A., Douglas, J. M., Malotte, K., Cross, H., Dillon, B. A., Paul, S. M., et al. (2005). Relative efficacy of prevention counseling with rapid and standard HIV testing: A randomized, controlled trial (RESPECT - 2). Sexually Transmitted Diseases, 32, 130 - 138. doi:10.1097/01.olq.0000 151421.97004.c0

Mullen, P. D., Ramirez, G., Strouse, D., Hedges, L. V., \& Sogolow, E. (2002). Meta-analysis of the effects of behavioral HIV prevention interventions on the sexual risk behavior of sexually experienced adolescents in controlled studies in the United States. Journal of Acquired Immune Deficiency Syndromes, 30, S94-S105. doi: 10.1097/01.QAI.0000019980.12814.DF

National Alliance of State and Territorial AIDS Directors [NASTAD]. (2005). Staggering rates among African American women, MSM and the incarcerated. Retrieved from http://www.thebody.com/ content/art6867.html

Neumann, M. S., Johnson, W. D., Semaan, S., Flores, S. A., Peersman, G., Hedges, L. V., \& Sogolow, E. (2002). Review and meta-analysis of HIV prevention intervention research for heterosexual adult populations in the United States. Journal of Acquired Immune Deficiency Syndromes, 30, S106S117. doi: 10.1097/01.QAI.0000018919.84759.50

O'Leary, A., Jemmott, L. S., \& Jemmott, J. B., III. (2008). Mediation analysis of an effective sexual riskreduction intervention for women: The importance of self-efficacy. Health Psychology, 27, S180 - S184. doi:10.1037/0278-6133.27.2(Suppl.).S180

Rhodes, S. D., Hergenrather, K. C., Duncan, J., Vissman, A. T., Miller, C., Wilkin, A. M. et al. (2010). A pilot intervention utilizing Internet chat rooms to prevent HIV risk behaviors among men who have sex with men. Public Health Reports, 125(Suppl. 1), 29-37.

Schneider, E. Glynn, M. K., Kajese, T., \& McKenna, M. T. (2006). Epidemiology of HIV/AIDS: United States 1981- 2005. Morbidity and Mortality Weekly Report, 55(21), 589 - 592. Retrieved from http://www.cdc.gov/mmwr/preview/mmwrhtml/mm5521a2.htm

Semaan, S., Des Jarlais, D. C., Sogolow, E., Johnson,W. D., Hedges, L. V., Ramirez, G., et al. (2002). A meta-analysis of the effect of HIV prevention interventions on the sex behaviors of drug users in the United States. Journal of Acquired Immune Deficiency Syndromes, 30, S73-S93. doi: 10.1097/01.QAI.0000017613.32101.90

Sharma, M., \& Romas, J. A. (2008). Theoretical foundations of health education and health promotion. (p. 30). Sudbury, MA: Jones and Bartlett Publishers.

Sikkema, K. J., Wilson, P. A., Hansen, N. B., Kochman, A., Neufeld, S., Ghebremichael, M. S.,et al. (2008). Effects of a coping intervention on transmission risk behavior among people living with HIV/AIDS and a history of childhood sexual abuse. Journal of Acquired Immune Deficiency Syndromes, 47, 506 - 513. doi:10.1097/QAI.0b013e318160d727

United States Department of Health and Human Services, Centers for Disease Control and Prevention. (2005). HIV/AIDS surveillance report 2004 (CDC Publication No. Vol. 6). Retrieved from http://www.cdc.gov/hiv/topics/surveillance/resources/reports/2004report/pdf/2004SurveillanceRe port.pdf

Wagner, K. D., Unger, J. B., Bluthenthal, R. N., Andreeva, V. A., \& Pentz, M. A. (2010). Cognitive behavioral theories used to explain injection risk behavior among injection drug users: A review and suggestions for the integration of cognitive and environmental models. Health Education \& Behavior, 37(4), 504-532.

Wingood, G. M., DiClement, R. J., Mikhail, I., Lang, D. L. L., McCree, D. H., Davies, S. L., et al. (2004). A randomized controlled trial to reduce HIV transmission risk behaviors and sexually transmitted diseases among women living with HIV; The WiLLOW program. Journal of Acquired Immune Deficiency Syndrome, 37, S58-S67.

World Health Organization [WHO]. (1988). London declaration on AIDS prevention. In AIDS prevention and control (pp. 122-124). New York: Pergamon. 
Author Information

Matthew Asare, MA, MBA*

University of Cincinnati

Health Promotion \& Education

Cincinnati, OH 45221-0068

Phone: (513) 556-3878

Fax : (513) 556-3898

asaremw@ucmail.uc.edu

Manoj Sharma, MBBS, CHES, Ph.D.

University of Cincinnati

Health Promotion \& Education

* corresponding author 


\section{Appendix}

Table 1

Summary of HIV/AIDS prevention interventions that utilized social cognitive theory

\begin{tabular}{|c|c|c|c|c|c|c|c|}
\hline Study \& year & Sample/ Setting & Study design & Intervention & Theory & $\begin{array}{c}\text { Focus } \\
\text { area/Target } \\
\text { behavior }\end{array}$ & Effect size* & Major findings \\
\hline $\begin{array}{l}\text { Wingood, et al. } \\
2004 .\end{array}$ & $\begin{array}{l}\text { Participant } \\
(\mathrm{n}=366) \text { African } \\
\text { American } \\
(84.2 \%) \text { mean } \\
\text { age } 34.7 \text { years } \\
\text { old. Clinic and } \\
\text { health } \\
\text { department based } \\
\text { intervention. }\end{array}$ & $\begin{array}{l}\text { RCT design. } \\
\text { Participants were } \\
\text { randomly assigned to } \\
\text { intervention group } \\
(\mathrm{n}=190) \text { and control } \\
\text { group }(\mathrm{n}=176)\end{array}$ & $\begin{array}{l}\text { Intervention group } \\
\text { received education } \\
\text { based on } \\
\text { WiLLOW 4-hour } \\
\text { program. } \\
\text { Components } \\
\text { include gender } \\
\text { pride, HIV } \\
\text { knowledge and } \\
\text { supportive } \\
\text { network }\end{array}$ & $\begin{array}{l}\text { Social cognitive } \\
\text { Theory }\end{array}$ & $\begin{array}{l}\text { Unprotected } \\
\text { vaginal } \\
\text { intercourse. } \\
\text { Proportion never } \\
\text { used condoms, } \\
\text { incident STDs, } \\
\text { psychosocial } \\
\text { factors, and } \\
\text { number of } \\
\text { supportive } \\
\text { network members }\end{array}$ & $\begin{array}{l}\text { Small effect } \\
\text { size }(0.08)\end{array}$ & $\begin{array}{l}\text { The participants in } \\
\text { intervention group } \\
\text { reported fewer } \\
\text { episodes of } \\
\text { unprotected } \\
\text { vaginal intercourse, } \\
\text { were likely to use } \\
\text { condom and have } \\
\text { knowledge and } \\
\text { high self efficacy } \\
\text { to use condom. }\end{array}$ \\
\hline $\begin{array}{l}\text { Legardy, } \\
\text { Macaluso, Artz, } \\
\text { \& Brill, } 2005 .\end{array}$ & $\begin{array}{l}\text { Participant } \\
(\mathrm{n}=427) \text { African } \\
\text { American }(87 \%), \\
\text { mean age } 25 \\
\text { years old. Clinic } \\
\text { based } \\
\text { intervention }\end{array}$ & $\begin{array}{l}\text { RCT design. } \\
\text { Participants } \\
\text { randomly assigned to } \\
\text { control group } \\
(n=214) \text { or } \\
\text { experimental group } \\
(n=213)\end{array}$ & $\begin{array}{l}\text { Component } \\
\text { includes advice } \\
\text { about STD, } \\
\text { brochure on } \\
\text { condom, } \\
\text { strengthened } \\
\text { women } \\
\text { communication. }\end{array}$ & $\begin{array}{l}\text { Social } \\
\text { Cognitive } \\
\text { Theory }\end{array}$ & Condom use & $\begin{array}{l}\text { Small effect } \\
\text { size }(0.08)\end{array}$ & $\begin{array}{l}\text { The enhanced } \\
\text { intervention group } \\
\text { had a } 60 \% \text { higher } \\
\text { consistent condom } \\
\text { use rate compared } \\
\text { to the basic group } \\
\text { (risk ratio [RR], } \\
1.6 ; 95 \% \\
\text { confidence interval } \\
\text { [CI], } 1.4-1.8 \text { ). }\end{array}$ \\
\hline $\begin{array}{l}\text { Jemmott, L.S., } \\
\text { Jemmott, \& } \\
\text { O'Leary, } 2007 .\end{array}$ & $\begin{array}{l}\text { Participants } \\
(\mathrm{n}=564) \text { African } \\
\text { American } \\
\text { women }(100) \text {. } \\
\text { Clinic based } \\
\text { intervention }\end{array}$ & $\begin{array}{l}\text { RCT design. } \\
\text { Participants were } \\
\text { randomly assigned to } \\
\text { either group skills } \\
\text { ( } \mathrm{n}=118), \text { group } \\
\text { intervention }(\mathrm{n}=124) \\
\text { one-on-one skills } \\
(\mathrm{n}=123), \text { One-on-one } \\
\text { information } \\
\text { group }(\mathrm{n}=118), \text { or } \\
\text { control group }(\mathrm{n}=81))\end{array}$ & $\begin{array}{l}\text { 200-munite } \\
\text { counseling } \\
\text { intervention } \\
\text { session on condom } \\
\text { use skills }\end{array}$ & $\begin{array}{l}\text { Social } \\
\text { Cognitive } \\
\text { Theory }\end{array}$ & $\begin{array}{l}\text { Primary outcome } \\
\text { was Self-report } \\
\text { sexual behavior } \\
\text { and secondary } \\
\text { outcome was } \\
\text { STDs incidence }\end{array}$ & $\begin{array}{l}\text { Small effect } \\
\text { size }(0.08)\end{array}$ & $\begin{array}{l}\text { Participants in the } \\
\text { intervention group } \\
\text { reported less } \\
\text { unprotected sexual } \\
\text { behavior after } \\
12 \text { months }\end{array}$ \\
\hline
\end{tabular}


Table 1 (continued). Summary of HIV/AIDS prevention interventions that utilized social cognitive theory

\begin{tabular}{|c|c|c|c|c|c|c|c|}
\hline Study \& year & Sample/ Setting & Study design & Intervention & Theory & $\begin{array}{c}\text { Focus } \\
\text { area/Target } \\
\text { behavior }\end{array}$ & Effect size* & Major findings \\
\hline $\begin{array}{l}\text { O'Leary, } \\
\text { Jemmott, L. S., \& } \\
\text { Jemmott, } 2008\end{array}$ & $\begin{array}{l}\text { Participants } \\
(\mathrm{n}=564) \text { African } \\
\text { American } \\
\text { women }(100) . \\
\text { Clinic based } \\
\text { intervention }\end{array}$ & $\begin{array}{l}\text { RCT design. } \\
\text { Participants were } \\
\text { randomly assigned to } \\
\text { either group skills } \\
(\mathrm{n}=118) \text {, group } \\
\text { intervention }(\mathrm{n}=124) \\
\text { one-on-one skills } \\
(\mathrm{n}=123), \text { One-on-one } \\
\text { information } \\
\text { group }(\mathrm{n}=118), \text { or } \\
\text { control group }(\mathrm{n}=81)\end{array}$ & $\begin{array}{l}\text { 200-munite } \\
\text { counseling } \\
\text { intervention } \\
\text { session on condom } \\
\text { use skills }\end{array}$ & $\begin{array}{l}\text { Social } \\
\text { Cognitive } \\
\text { Theory }\end{array}$ & $\begin{array}{l}\text { Condom use } \\
\text { knowledge, } \\
\text { hedonistic beliefs } \\
\text { about effects of } \\
\text { condom use, self- } \\
\text { efficacy: for } \\
\text { condom use, for } \\
\text { carrying condoms } \\
\text { for impulse } \\
\text { control }\end{array}$ & $\begin{array}{l}\text { Small effect } \\
\text { size }(0.08)\end{array}$ & $\begin{array}{l}\text { The intervention } \\
\text { significantly } \\
\text { improved all } \\
\text { hedonistic beliefs } \\
\text { and self-efficacy } \\
\text { for impulse } \\
\text { control. }\end{array}$ \\
\hline $\begin{array}{l}\text { Sikkema, et al., } \\
2008\end{array}$ & $\begin{array}{l}\text { Participants } \\
(\mathrm{n}=247) \text { African } \\
\text { American } 85 \% \\
\text { Community } \\
\text { health care clinic } \\
\text { setting }\end{array}$ & $\begin{array}{l}\text { RCT design. } \\
\text { Participants were } \\
\text { randomly assigned to } \\
\text { either coping group } \\
\text { ( } \mathrm{n}=124 \text { ) or support } \\
\text { group }(\mathrm{n}=123)\end{array}$ & $\begin{array}{l}\text { 15-weekly } 90- \\
\text { minute sessions } \\
\text { intervention } \\
\text { includes problem } \\
\text { solving, } \\
\text { communication } \\
\text { skills, } \\
\text { identification of } \\
\text { individual triggers } \\
\text { etc. Risk reduction } \\
\text { skills }\end{array}$ & $\begin{array}{l}\text { Cognitive } \\
\text { theory of stress } \\
\text { and coping }\end{array}$ & Sexual behavior & $\begin{array}{l}\text { Small effect } \\
\text { size }(0.08)\end{array}$ & $\begin{array}{l}\text { Participants in the } \\
\text { HIV and trauma } \\
\text { coping intervention } \\
\text { decreased their } \\
\text { frequency of } \\
\text { unprotected sexual } \\
\text { intercourse more } \\
\text { than those in the } \\
\text { support group. }\end{array}$ \\
\hline $\begin{array}{l}\text { El-Bassel, et. al } \\
2010\end{array}$ & $\begin{array}{l}\text { Participants }(\mathrm{n}= \\
535 \text { couples }) \\
\text { African } \\
\text { American } 100 \% . \\
\text { Mean age } 43.41 \\
\text { years old. } \\
\text { Multisite-based } \\
\text { intervention }\end{array}$ & $\begin{array}{l}\text { RCT design. } \\
\text { Participants were } \\
\text { randomly assigned to } \\
\text { either Risk reduction } \\
\text { group ( } n=260 \\
\text { couples) or health } \\
\text { promotion group } \\
\text { ( } n=275 \text { couples) }\end{array}$ & $\begin{array}{l}\text { 8-weekly } \\
\text { structured 2-hour } \\
\text { sessions based on } \\
\text { based on Afro- } \\
\text { centric paradigm } \\
\text { and historical and } \\
\text { cultural beliefs }\end{array}$ & $\begin{array}{l}\text { Social cognitive } \\
\text { Theory }\end{array}$ & $\begin{array}{l}\text { Primary } \\
\text { behavioral } \\
\text { outcome was the } \\
\text { couple's reported } \\
\text { condom protected } \\
\text { intercourse and } \\
\text { consistent condom } \\
\text { use }\end{array}$ & $\begin{array}{l}\text { Small effect } \\
\text { size }(0.06)\end{array}$ & $\begin{array}{l}\text { The proportion of } \\
\text { condom-protected } \\
\text { intercourse acts } \\
\text { was larger among } \\
\text { couples in the } \\
\text { intervention group } \\
\text { than the } \\
\text { comparison group. }\end{array}$ \\
\hline
\end{tabular}

*The mean effect size for the six interventions that utilized Social Cognitive Theory 0.08 
Table 2

Summary of HIV/AIDS prevention interventions that utilized other behavioral theories and models

\begin{tabular}{|c|c|c|c|c|c|c|c|}
\hline Study \& year & Sample/ Setting & Study design & Intervention & Theory & $\begin{array}{c}\text { Focus } \\
\text { area/Target } \\
\text { behavior } \\
\end{array}$ & Effect size* & Major findings \\
\hline $\begin{array}{l}\text { Kalichman, Cain, } \\
\text { Presser, } \\
\text { Bjodstrup, \& } \\
\text { Swain, 2005. }\end{array}$ & $\begin{array}{l}\text { Participants } \\
(\mathrm{n}=612) \text { African } \\
\text { American }(85 \%) \\
\text { Mean age } 35.3 \\
\text { years old. Clinic } \\
\text { based } \\
\text { intervention }\end{array}$ & $\begin{array}{l}\text { RCT design. } \\
\text { Participants were } \\
\text { randomly } \\
\text { assigned to either } \\
\text { I }(n=147) \text {, } \\
\text { IM }(n=143) \text {, } \\
\text { IB }(n=136) \text { or } \\
\text { IMB }(n=132)\end{array}$ & $\begin{array}{l}\text { A 90-minute } \\
\text { counseling } \\
\text { session includes } \\
\text { counseling, } \\
\text { feedback, skill } \\
\text { building }\end{array}$ & $\begin{array}{l}\text { Information- } \\
\text { Motivation } \\
\text { behavioral skills } \\
\text { model }\end{array}$ & $\begin{array}{l}\text { Knowledge of } \\
\text { HIV/AIDS, HIV } \\
\text { prevention } \\
\text { behavioral } \\
\text { intention, Self- } \\
\text { efficacy for } \\
\text { condom use, } \\
\text { sexual behavior } \\
\text { outcome }\end{array}$ & $\begin{array}{l}\text { Small effect size } \\
(0.07)\end{array}$ & $\begin{array}{l}\text { Significant } \\
\text { increase in HIV } \\
\text { knowledge } \\
\text { among all the } \\
\text { participants. } \\
\text { Over participants } \\
\text { in IMB showed } \\
\text { greater use of } \\
\text { risk reduction } \\
\text { skills to lower } \\
\text { unprotected sex }\end{array}$ \\
\hline $\begin{array}{l}\text { Metcalf et al., } \\
2005 .\end{array}$ & $\begin{array}{l}\text { Participants } \\
(\mathrm{n}=3297) \text { African } \\
\text { American }(51 \%) \\
\text { Mean age 25.6 } \\
\text { year old. Clinic } \\
\text { based } \\
\text { intervention }\end{array}$ & $\begin{array}{l}\text { RCT design. } \\
\text { Participants were } \\
\text { randomly } \\
\text { assigned to either } \\
\text { rapid-test } \\
(\mathrm{n}=1648) \text { or } \\
\text { standard test } \\
(\mathrm{n}=1649)\end{array}$ & $\begin{array}{l}2 \text { counseling } \\
\text { sessions about } 30 \\
\text { to } 40 \text { minutes. } \\
\text { Based on } \\
\text { modified version } \\
\text { of CDC's Project } \\
\text { RESPECT-2. }\end{array}$ & $\begin{array}{l}\text { Based on several } \\
\text { theoretical } \\
\text { models }\end{array}$ & $\begin{array}{l}\text { Primary outcome } \\
\text { were STDs - } \\
\text { gonorrhea, } \\
\text { Chlamydia, } \\
\text { trichomoniasis, } \\
\text { syphilis, HIV }\end{array}$ & $\begin{array}{l}\text { Small effect size } \\
(0.02)\end{array}$ & $\begin{array}{l}\text { STD incidence } \\
\text { was higher in the } \\
\text { rapid-test group } \\
\text { than in the } \\
\text { standard-test } \\
\text { group. }\end{array}$ \\
\hline $\begin{array}{l}\text { Ehrhardt et al., } \\
2002\end{array}$ & $\begin{array}{l}\text { Participant } \\
(\mathrm{n}=360) \text { African } \\
\text { American } \\
(72.5 \%) \text { mean } \\
\text { age } 22.26 \text { year } \\
\text { old. Clinic based } \\
\text { intervention }\end{array}$ & $\begin{array}{l}\text { RCT design. } \\
\text { Participants } \\
\text { randomly } \\
\text { assigned to } \\
\text { Interview only } \\
(\mathrm{n}=120) 4 \\
\text { session }(\mathrm{n}=128) 8 \\
\text { session }(\mathrm{n}=112)\end{array}$ & $\begin{array}{l}\text { Based on AIDS } \\
\text { risk reduction } \\
\text { model. }\end{array}$ & $\begin{array}{l}\text { AIDS Risk } \\
\text { Reduction Model }\end{array}$ & $\begin{array}{l}\text { Reduction of } \\
\text { unprotected sex } \\
\text { and condom use }\end{array}$ & $\begin{array}{c}\text { Small effect size } \\
(0.09)\end{array}$ & $\begin{array}{l}\text { The women in } \\
\text { both intervention } \\
\text { groups reported } \\
\text { reduction in } \\
\text { unprotected sex } \\
\text { at six and } 12 \\
\text { months follow up }\end{array}$ \\
\hline
\end{tabular}

*The mean effect size of those three interventions is 0.06 
Table 3

Summary of HIV/AIDS prevention interventions that are atheoretical

\begin{tabular}{|c|c|c|c|c|c|c|c|}
\hline Study \& year & Sample/ Setting & Study design & Intervention & Theory & $\begin{array}{c}\text { Focus } \\
\text { area/Target } \\
\text { behavior } \\
\end{array}$ & Effect size* & Major findings \\
\hline $\begin{array}{l}\text { Hobfoll, Jackson, } \\
\text { Lavin, Johnson, } \\
\& \text { Schroder, } \\
2002 .\end{array}$ & $\begin{array}{l}\text { Participant } \\
(\mathrm{n}=935) \text { African } \\
\text { American }(55 \%) \\
\text { mean age } 21.42 \\
\text { years old. Clinic } \\
\text { and community } \\
\text { based } \\
\text { intervention }\end{array}$ & $\begin{array}{l}\text { RCT design } \\
\text { participants were } \\
\text { randomly } \\
\text { assigned to AIDS } \\
\text { prevention, } \\
(\mathrm{n}=361) \text { Health } \\
\text { promotion } \\
(\mathrm{n}=368) \text { and } \\
\text { standard care } \\
(\mathrm{n}=206)\end{array}$ & $\begin{array}{l}\text { AIDS specific } \\
\text { skills and } \\
\text { knowledge, } \\
\text { communication } \\
\text { skills include } \\
\text { negotiation, role } \\
\text { play. }\end{array}$ & $\begin{array}{l}\text { No theoretical } \\
\text { framework }\end{array}$ & $\begin{array}{l}\text { Condom use and } \\
\text { safer sex } \\
\text { behavior }\end{array}$ & $\begin{array}{l}\text { Small effect size } \\
(0.06)\end{array}$ & $\begin{array}{l}\text { The two } \\
\text { intervention } \\
\text { groups reported } \\
\text { significantly } \\
\text { greater use of } \\
\text { condoms than the } \\
\text { standard care } \\
\text { group. }\end{array}$ \\
\hline Abel, 2007 & $\begin{array}{l}\text { Participants } \\
(\mathrm{n}=44) \text { African } \\
\text { American } 75 \% \text {. } \\
\text { Community } \\
\text { based } \\
\text { intervention }\end{array}$ & $\begin{array}{l}\text { Participants were } \\
\text { randomly } \\
\text { assigned to either } \\
\text { experimental } \\
\text { group }(n=21) \text { or } \\
\text { control group } \\
(n=23) \text {. }\end{array}$ & $\begin{array}{l}\text { Intervention } \\
\text { consists of } \\
\text { writing negative } \\
\text { and positive } \\
\text { emotion words }\end{array}$ & $\begin{array}{l}\text { No theoretical } \\
\text { Framework }\end{array}$ & $\begin{array}{l}\text { Perception about } \\
\text { HIV related } \\
\text { stigma }\end{array}$ & $\begin{array}{l}\text { Medium effect } \\
\text { size }(0.27)\end{array}$ & $\begin{array}{l}\text { The experimental } \\
\text { group reported } \\
\text { significant } \\
\text { improvement in } \\
\text { perceived HIV- } \\
\text { related stigma } \\
\text { scores than the } \\
\text { control group }\end{array}$ \\
\hline $\begin{array}{l}\text { Crosby, } \\
\text { DiClemente, } \\
\text { Charnigo, Snow, } \\
\text { \& Troutman, } \\
2009\end{array}$ & $\begin{array}{l}\text { Participants } \\
(\mathrm{n}=266) \text { African } \\
\text { American women } \\
\text { 100\%. Mean age } \\
23.1 \text { years old. } \\
\text { Clinic based } \\
\text { intervention }\end{array}$ & $\begin{array}{l}\text { RCT design. } \\
\text { Participants were } \\
\text { randomly } \\
\text { assigned to either } \\
\text { single session } \\
\text { intervention } \\
(n=141) \text { or } \\
\text { standard care } \\
(n=125)\end{array}$ & $\begin{array}{l}45-50 \text { minutes } \\
\text { long intervention } \\
\text { based on } \\
\text { information, } \\
\text { motivation, and } \\
\text { behavioral skills }\end{array}$ & $\begin{array}{l}\text { No theoretical } \\
\text { framework }\end{array}$ & $\begin{array}{l}\text { Primary outcome } \\
\text { STD, and other } \\
\text { outcome multiple } \\
\text { sexual partners, } \\
\text { condom use, } \\
\text { proficiency in } \\
\text { using condoms }\end{array}$ & $\begin{array}{l}\text { Small effect size } \\
(0.11)\end{array}$ & $\begin{array}{l}\text { Participants in } \\
\text { the intervention } \\
\text { group were } \\
\text { significantly less } \\
\text { likely to acquire } \\
\text { STDs and more } \\
\text { likely to use } \\
\text { condom than } \\
\text { those in control } \\
\text { group }\end{array}$ \\
\hline
\end{tabular}

\footnotetext{
* The mean effect size for the three atheoretical interventions is 0.15
} 